\title{
Designing Global Sourcing Strategy for Cost Savings and Innovation: A Configurational Approach
}

\author{
Nidthida $\operatorname{Lin}^{1}$ (D)
}

Received: 6 March 2020 / Revised: 20 August 2020 / Accepted: 14 October 2020 /

Published online: 19 November 2020

(c) Springer-Verlag GmbH Germany, part of Springer Nature 2020

\begin{abstract}
Despite the well-acknowledged benefits of global sourcing (e.g., location specific advantage) in the international business literature, research driven mainly by the transaction cost economics and resource based view has cautioned about its potential negative effects (e.g., hidden costs, hollowing out effect) which might offset its potential gain, leading to a failure to achieve expected outcome and capture the value created in global sourcing activities. We argue that this issue is primarily explained by the misalignment between a firm's global sourcing strategy and value expected from its global sourcing activities. This study examines the role of global sourcing strategy on financial and innovation performance of global sourcing activities. Using a fuzzy set qualitative comparative analysis on 235 firms engaging in global sourcing of business service activities, we identify configurations of global sourcing strategy - concerning (1) disaggregation, (2) dispersion of activities and (3) governance structure - that lead to high financial and innovation performance. The findings suggest that global sourcing strategy leading to high financial performance differs largely from global sourcing strategy leading to high innovation. While most studies selectively focus on one or two components of global sourcing strategy, our study highlights the need for firms to jointly consider the combined effect of degree of disaggregation, degree of dispersion of business service activities and governance structure as well as taking into account the expected outcome when crafting their global sourcing strategy.
\end{abstract}

Keywords Global sourcing · Offshoring · Global value chain · Cost savings · Innovation · Configurations

Nidthida Lin

nidthida.lin@mq.edu.au

1 Macquarie Business School, Macquarie University, Sydney, NSW, Australia 


\section{Introduction}

Despite the critical role of global sourcing in revolutionizing how firms carry out their business process activities, we have observed mixed outcomes of success and failure in global sourcing activities. Various benefits including cost reduction (Ellram et al. 2008; Holcomb and Hitt 2007), access to global knowledge and skill (Lewin et al. 2009a; Lewin and Peeters 2006), increased innovation (Lewin et al. 2009a; Roza et al. 2011) and organizational flexibility (Massini et al. 2010) have driven firms to engage in global sourcing. However, many firms have come to realize that as their global sourcing portfolio becomes more complex they increasingly suffer from inefficiency in their global sourcing activities, which drives up the costs and leads to the failure to capture value expected from their global network of value chains (Barthelemy 2003; Dibbern et al. 2008; Jha et al. 2018; Larsen et al. 2012). The natural question that follows, yet remains unclear in the literature, is what is required for firms to organize their global sourcing activities successfully. This study aims to shed light on this important question.

Building on Kedia and Mukherjee's (2009) seminal work, Contractor, Kumar, Kundu and Pedersen (2010) provides us with a comprehensive understanding of the critical decisions underlying global sourcing strategy, involving an optimal degree of both disaggregation of value chain activities and dispersion of such activities geographically (i.e., location choice) and organizationally (i.e., governance choice). A decision on the degree of disaggregation is informed mostly by the traditional classification of core vs. non-core activities and the concept of modularity in business processes (Baldwin and Clark 1997, 2000; Sako 2006), while studies on the degree of global dispersion and location choices draw on the international business literature concerning a thorough consideration of managing across distance (i.e., physical, cultural, linguistic and institutional distance). Further, governance decisions-outsourcing versus captive-are mainly examined from the transaction cost economics lens (Gereffi et al. 2005; Hutzschenreuter et al. 2011a; Nieto and Rodríguez 2011). Although these theoretical lenses contribute significantly to our understanding of global sourcing, most research has focused mainly on a specific aspect of global sourcing and, hence, overlooked a holistic view of global sourcing management (see Mihalache and Mihalache 2020; Mukherjee and Kedia 2012; Thakur-Wernz and Bruyaka 2017). We propose here a need for global sourcing research to incorporate all three components-disaggregation, geographical dispersion, and organizational dispersion-of global sourcing configuration and take into account their joint effects on the global sourcing activities. This gap has left the search for an efficient global sourcing strategy fragmented and, hence, failed to yield the expected outcome.

To fill this gap and enhance our understanding of the global sourcing strategy, this study incorporates all three components of global sourcing strategy and examines the global sourcing configurations of business services leading to high performance both in terms of cost savings and innovation. More specifically, we take a configurational approach to explicate the complex relationships among disaggregation, geographical dispersion and organizational dispersion (i.e., governance mode) of firms' global sourcing portfolio and identify the combinations of 
these three components (i.e., global sourcing configurations) that lead to (1) high cost savings and (2) high innovation in global sourcing activities. In essence, we argue that high performing global sourcing configurations are driven not only by specific elements but also the alignment among these three components to ensure that they work synchronously toward the expected outcome.

Using the data on the business service offshoring projects of 235 firms across countries, we adopt the fuzzy set qualitative comparative analysis (fsQCA) to analyze global sourcing configurations - combinations of a degree of disaggregation, degree of geographical dispersion and governance mode-leading to high cost savings and innovation in global sourcing activities. The advantage of the configurational approach is that it allows us to disentangle complex interdependencies among variables leading to high cost savings and those leading to high innovation. The configurational approach also captures equifinality which overcomes the limitation of the single dominant net-effect explanation in the traditional regression by allowing different pathways (i.e., various combinations of three components of global sourcing configuration) to the same expected outcome (i.e., high performance). Further, fsQCA approach is based on set-theoretic relations, rather than the traditional correlations, which make it more appropriate for examining causal relations.

This study contributes to the global sourcing and offshoring literature in three ways. First, we extend research on global sourcing by employing a configurational approach to examine how a combination and interaction of degree of disaggregation, geographical dispersion and governance mode influence cost savings and innovation outcome of global sourcing activities. To our knowledge, we are among the first attempt to empirically examine all three components-disaggregation, geographical dispersion and governance structure — of global sourcing strategy and their effect on global sourcing performance in a single study (Albertoni et al. 2017 is the only study we know of that examines the effect of these three components but on reshoring decision). Table 1 summarizes examples of research examining disaggregation, geographical dispersion, governance structure or a combination of these components on the performance of global sourcing. Our findings suggest that high performing (both in terms of cost savings and innovation) global sourcing configurations are not driven solely by a single component but require the right combination of three components to deliver successful outcome. We also found that there is no single configuration that leads to both high cost savings and high innovation and that global sourcing configurations leading to high cost savings differ primarily from configurations leading high innovation outcome.

Second, we contribute to the international business literature by extending our understanding of the role of (both geographical and cultural) distance on the outcome of global sourcing. More specifically, while research has indicated the significant effect of distance in MNCs performance (Ambos and Ambos 2009; Hutzschenreuter et al. 2014), our study suggests that the effect of distance is not discrete. Hence, it is important to consider also its effect in conjunction with other elements (i.e., degree of disaggregation and governance mode) of global sourcing configuration in order to accurately understand the role of distance on the performance outcome of global sourcing. 


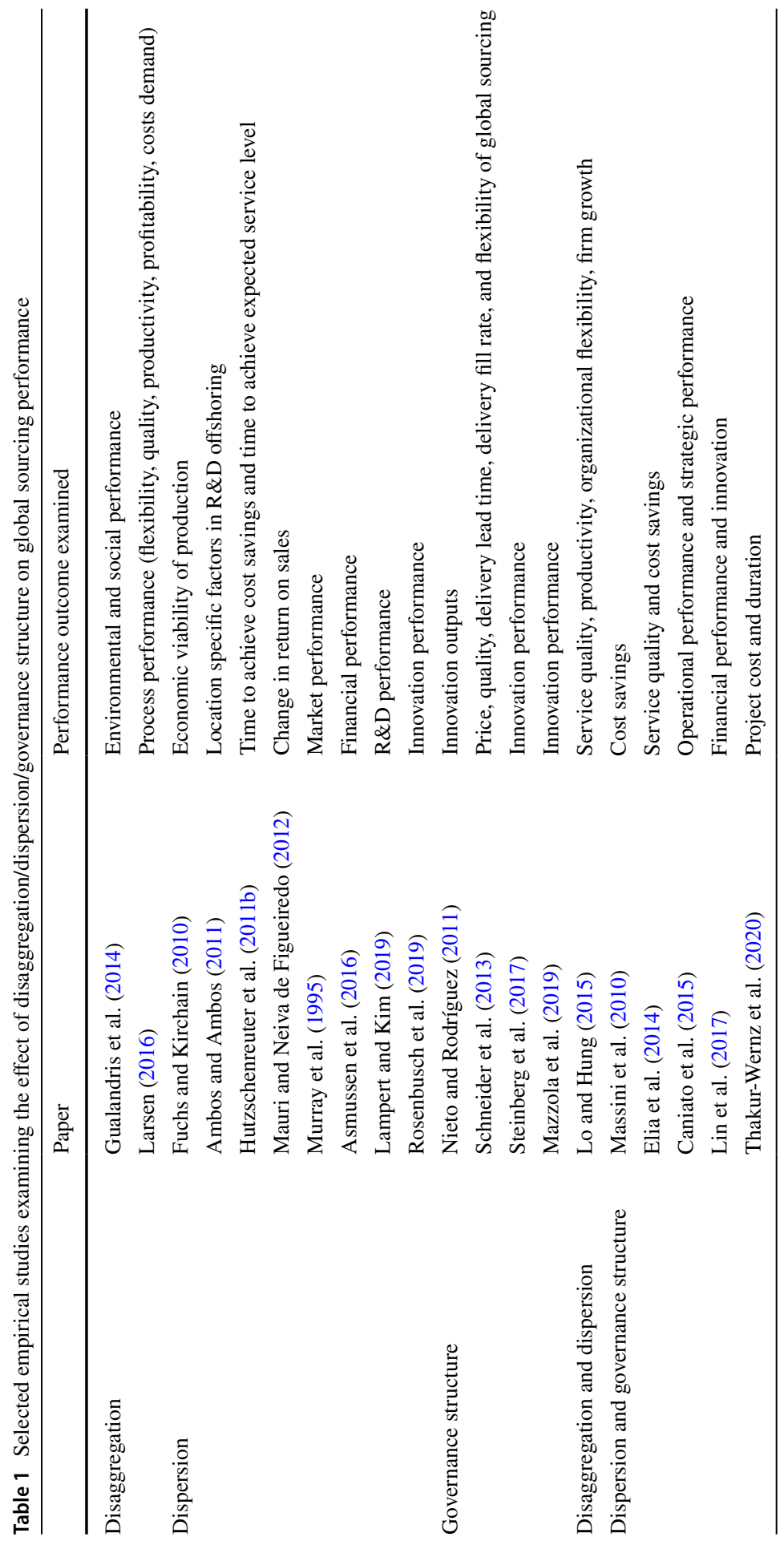


Finally, our study sheds light on the inconsistent research findings and ongoing debate on the role of governance mode on the success of global sourcing (e.g., Hutzschenreuter et al. 2011b; Rodríguez and Nieto 2016; Roza et al. 2011). By considering the combined effect, rather than the net effect, of governance mode and other aspects of global sourcing configuration, we are able to provide a better explanation of how the level of control influences the outcome and performance of global value sourcing activities.

\section{Theoretical Background}

For a few decades, firms, especially in developed countries, have increasingly adopted the concept of global sourcing which allow them to slice up activities in their value chain (refer to Cohen and Mallik 1997 and Porter 1985 for the original discussion of global value chain) and globally distribute them to locations where they can be best sourced. Several terms, such as global value chain, offshoring, globally distributed activities, and global factory have been used to loosely refer to the phenomenon of global sourcing. Global sourcing describes the range of activities that firms carry out on a global scale to bring a product or service to end use (Gereffi et al. 2005). The crucial element in global sourcing is the efficient planning and coordination of globally distributed activities in order to reduce friction and transaction cost and, at the same time, to gain access to diverse sources of knowledge, skill, and talent available in various locations. Building on Kedia and Mukhejee's (2009) Disintegration-Location-Externalization (DLE) framework, Contractor et al. (2010) suggest that firms strategically determine the optimal combination of (1) disaggregation, (2) geographical dispersion and (3) organizational dispersion (i.e., governance mode) of their value chain activities in order to achieve the maximum global firm value. In this study, we draw on these three components of global sourcing configuration suggested by Contractor et al. (2010) to examine the optimal configurations of global sourcing activities. A decision on the disaggregation of activities is primarily informed by research attempting to classify value chain activities using various criteria including types of an activity (e.g., upstream, downstream), potential for competence creation (e.g., exploration vs. exploitation activity), and potential for being a source of competitive advantage (e.g., core vs. non-core activity). When making a dispersion decision, firms need to consider both the geographical and organizational aspect of their value chain dispersion (Contractor et al. 2010). Geographical dispersion, extensively discussed in the international business literature, involves a decision to source an activity from a location where there exists a skilled workforce to perform the activity at a competitive cost. Organizational dispersion or governance structure, driven mainly by the firm boundary literature, concerns a choice of appropriate organization form to govern dispersed value chain activities, ranging from captive (wholly owned) to outsourcing (market mode) or the mix of these two governance modes (e.g., strategic joint venture).

We discuss below these three critical components of global sourcing strategy and how each of them contributes to the cost savings and innovation outcome of global sourcing activities. 


\subsection{Disaggregating Firm's Value Chain}

The disaggregation of value chains (also called disintegration of value chains) refers to a phenomenon when one or more components in the value chain are decomposed into discrete modules and dispersed to be performed by different parties (Contractor et al. 2010). The process of value chain disaggregation requires firms to carefully examine activities along their value chain to assess both the feasibility as well as costs and benefits of modularizing the whole process into separable discrete activities. To understand the concept of disaggregating a value chain, we draw on two streams of literature: modularity and the resource-based view of the firm.

Research in modularity and knowledge management suggests that a component in the value chain can be disaggregated when it can be standardized, routinized, and codified (Contractor et al. 2010). The concept of modularity was proposed in Baldwin and Clark's (1997) seminal work, which demonstrates the power of modularity in product design and manufacturing. Management scholars have since applied the concept of modularity to further explain other complex systems including, for example, organization architecture (Schilling 2000; Schilling and Steensma 2001) and outsourcing (Sako 2003). As with modular product architecture, organization units and tasks are modular if they have strong interdependence within themselves and independence between units or components. From the modularization perspective, global sourcing is fundamentally the disaggregation of activities along the value chain into separable tasks and dispersion of these separable tasks to be performed by teams across geographical locations. In the process of value chain modularization, an explicitly defined and standardized interface between the discrete activities is critical as it allows for a smooth disaggregation and reintegration of value chain activities.

The resource-based view (RBV) has been extensively used in international business (see Peng 2001) and, more specifically, outsourcing and offshoring literature to explain firms' decision on which activities can be disaggregated and outsourced. The concept of core competencies is among the most powerful frameworks researchers draw on to explain why a particular activity in a value chain can be disaggregated and dispersed to be performed in other locations (e.g., Gilley and Rasheed 2000; Teng et al. 1995). More specifically, this approach suggests that firms classify discrete activities in their value chain into core and non-core activities (Prahalad and Hamel 1990), focus on those constituting core competencies, and disperse the rest to specialized service providers (Apte and Mason 1995; Quinn and Hilmer 1994). By defining their possession of resources and capabilities, firms distinguish core activities contributing to their core competencies and identify which activities must be performed in-house and which can be disaggregated and source globally from where it can be performed more efficiently (Espino-Rodríguez and PadrónRobaina 2006). A clear administrative separation along a value chain emerges as an activity and information become standardized, and coordination across value chain activities is simplified (Jacobides 2005; Richardson 1972). Hence, disaggregation of value chains is determined not only by the potential for focusing resources on activities that are critical to a firm's core competencies, but also by the potential for economic value through an access to more valuable specialized capabilities (Murray 
and Kotabe 1999). Research further highlights that the importance of value capture, particularly when disaggregated activities involve proprietary assets or intellectual properties, in this process and the need to proactively take into account value capturing mechanism when making a decision to disaggregate value chain activities (Roy and Sivakumar 2011).

Nevertheless, research has pointed out several adverse effects of value chain disaggregation. Difficulties in coordination and communication are often the main challenge in the disaggregation of value chains (Mukherjee et al. 2013), especially activities with high interdependence. As suggested in the modularity literature (Baldwin and Clark 1997, 2000; Sako 2003), the issue of coordination and communication requires a well-designed interface to ensure that independent tasks along the value chain, which are now performed by different teams, work seamlessly with each other. Research in innovation sourcing and knowledge management also has raised a concern on the issue of knowledge leakage and potential violation of intellectual property when high-value activities (e.g., those involving proprietary knowledge) are disaggregated and dispersed to external service providers (Nieto and Rodríguez 2011; Pisani and Ricart 2018). Disaggregation of value chain might also lead to the difficulty to ensure the quality and time requirement due to the lack of control (Kedia and Mukherjee 2009; Mudambi and Venzin 2010). Both geographical and organizational separation, discussed in the next section, make it even more complex and, hence, costly for firms to monitor the progress of a task and to take corrective actions. An appropriate degree of disaggregation of value chain activities is, hence, an important component in the global sourcing strategy as firms need to ensure that the positive effect of value chain disaggregation outweighs its negative effect.

\subsection{Global Dispersion of Value Chain Activities}

Dispersion of value chain activities follows the process of disaggregation as firms reallocate discrete tasks in their value chain to be performed by internal and external parties (i.e., governance choice) across geographical boundaries (location choice). A decision on the degree of geographical dispersion has been extensively discussed in the international business literature-more specifically in multinational company (MNC), offshoring and global sourcing research-with a focus on the role of physical and cultural distance on globally dispersed units. This stream of research entails the relocation of operations from a home country to foreign locations where the same activities are performed either by MNC's subsidiary or external service providers.

Dunning (1993)'s internationalization theory and its extension, Kedia and Mukherjee's (2009) DLE (Disintegration, Location, and Externalization) framework, provide a fundamental explanation to the incentives for firms to disperse their value chain activities. This stream of research emphasizes the role of location-specific advantages on a decision to disperse value chain activities. Location-specific advantages are market factors that are specific to a country (or location within a country) and enable firms to benefit from its resources, networks, and institutional structures (Dunning 1980). These also include Ricardian resource endowments and 
institutional environment, which endowments are used (Dunning 1980; Singh and Kundu 2002).

Four key location-specific advantages are identified for the dispersion of value chain activities (Kedia and Mukherjee 2009). First, firms may disperse their activities to foreign locations for the advantage of labor arbitrage (Kogut 1985). Cost of labor usually accounts for a significant portion of operational cost and, hence, a reduction of labor cost by utilizing inexpensive labor pool in emerging economies motivates firms to engage in global dispersion of their value chain activities. Second, given that a great deal of knowledge and intellectual capital are scattered around the world, access to such skills and knowledge can create value to firms in the form of knowledge arbitrage. The superior capability of human capital in foreign locations together with the deficiency of skilled professional, especially in STEM (Science, Technology, Engineering and Mathematics) area, in developed countries leads firms to search for knowledge arbitrage by sourcing their activities from foreign locations (Lahiri et al. 2012; Lewin et al. 2009a). Third, the dispersion of value chain activities allows firms to reap the benefit of time arbitrage (Carmel 2006). Time arbitrage arises from the difference in time zone between locations which enables a task to be performed around the clock. This significantly increases productivity and decreases product and service turnaround time. Finally, government support and infrastructure in some foreign locations also provide an incentive for firms to offshore their business service activities to such locations. Indian, Chinese and Malaysian government, for example, have actively promoted their global service-provider industry by creating investment-friendly policies, improving national infrastructures, and offering high-quality and affordable labor to attract global sourcing activities from foreign firms (Kearney 2014; Lewin et al. 2009b).

A stream of research focusing on the role of distance on multinational companies highlights the benefits and costs of global dispersion of value chain activities. While several aspects of distance have been extensively discussed in the international business literature, geographical and cultural distance are the two main dimensions of distance shown to play a major role in international business activities. Geographical distance (also called physical distance or spatial distance) is shown to have a significant effect on MNC's strategic decisions including cross-border joint venture (Zaheer and Hernandez 2011) and globally dispersed units (Schleimer and Riege 2009). The research found that geographical distance among globally dispersed activities results in difficulties in coordination and communication between teams and, hence, creates a barrier in the transfer of knowledge and innovation across teams ( Ambos and Ambos 2009; Chen and Lin 2018; Hansen et al. 1999). On the other hand, global dispersion of value chain activities allows firms to gain access to skills and knowledge sources available in various foreign locations (Lewin et al. 2009a). Research further points out that apart from geographical distance offshoring firms need to consider also cultural distance, referring to differences in norms, values, and beliefs across countries (Hofstede 1983). Cultural distance is identified as one of the invisible costs in offshoring activities (Stringfellow et al. 2008). Small cultural distance between dispersed teams is shown to facilitate communication and knowledge transfer between teams as well as to reduce transaction costs in the process. However, too close cultural distance can pose a negative effect on global 
dispersion of value chain activities as it often leads to local inertia, which constrains collective learning in globally dispersed teams (Boschma 2005; Carmel et al. 2010). Hence, it is critical that firms carefully manage the degree of dispersion-both in terms of geographical and cultural dispersion-in order to reap the maximum benefits of their global sourcing activities.

\subsection{Governance Mode of Global Sourcing Activities}

Organizational dispersion or governance mode is another crucial component contributing to the outcome and success of global sourcing (Kedia and Mukherjee 2009; Mudambi 2008; Pisani and Ricart 2016). Governance mode decision is a firm's choice to vertically integrate (so-called captive offshoring) or outsource value chain activities to external service providers (so-called offshore outsourcing). Transaction cost economics (TCE) offers a theoretical framework for explaining a firm's choice of governance in global value chain activities (Williamson 2008). According to TCE, a firm's governance choice rests on its effort to minimize costs arising from the governance of market exchange. In other words, TCE suggests that firm's choice on governance mode of their global sourcing activities depends largely on costs incurring from its attempt to minimize opportunistic behavior of an external provider (Williamson 1991). This rationale suggests that firms disaggregate their value chain and disperse activities to external providers only if costs from opportunism and bounded rationality are kept at the minimum. Combining both transaction cost economics and resource-based view, Holcomb and Hitt (2007) argue that outsourcing of value chain activities allows firms to rely on the intermediate market to provide specialized capabilities that supplement their internal capabilities deployed along their value chain.

Governance mode is, hence, a strategic decision with several implications on the outcome of global sourcing activities. First, governance mode directly determines the degree of control a firm has on its offshore activities. This level of control allows firms to closely monitor and mandate how an activity is performed as well as its quality. On the other hand, while outsourcing allows firms to free up their limited resources to focus on the "core" business activities (Holcomb and Hitt 2007; Quinn and Hilmer 1994), it may lead to the loss of control over outsourced activities and, hence, impact the quality of the outcome. In several cases, too much reliance on external service providers caused the hollowing-out effect which puts a firm in a vulnerable position to service providers' opportunistic behaviors (Kotabe 1989; Kotabe and Murray 2004) as well as to environmental shock and crisis (e.g., COVID-19) causing global supply chain disruption (Levy 1995) and leads to a decline in internal capability and knowledge and an increase in operating costs of global sourcing activities (Quinn and Hilmer 1994).

Second, the governance mode specifies the amount of effort required for firms to perform an offshore activity. Internal governance mode-wholly owned subsidiary or offshore captive-involves a higher commitment in the firm's resources, time, and investment compared to external governance mode. Given its minimal investment, outsourcing in most cases offers a quick cost reduction and access to potentially new 
set of skill and knowledge not available inside a firm, thereby benefiting both cost savings and innovation outcome of global sourcing activities. However, despite the advantage of labor arbitrage and economies of scale, outsourcing faces challenges in communication and coordination across the firm and geographical boundaries, which might outweigh the benefit of cost savings (Chen and Lin 2016; Lin et al. 2017).

Third, the level of risks associated with global sourcing is influenced by the governance mode adopted by a firm. On one hand, offshore outsourcing is prone to the risk of opportunistic behavior of external service providers (Holcomb and Hitt 2007), leading to an increase in transaction costs which in many cases are not taken into account ex-ante (Williamson 2008), so-called hidden costs of global sourcing (Larsen et al. 2012). This line of argument is consistent with Hymer's (1976) early work suggesting that multinational firms internalize activities involving high bonding and monitoring costs while relying on the market structure to perform activities with low bonding and monitoring costs. On the other hand, captive offshoring poses challenges as firms face a steep learning curve in navigating through offshore operations by themselves, which can become more intensified with a lack of local knowledge (Johanson and Vahlne 1977). Despite these risks, captive offshoring is shown to protect firms from service provider's opportunistic behavior and knowledge leakage. In particular, research shows that when outsourcing high-value activities (e.g., innovation, R\&D) to emerging economies, firms are at risk of sensitive information and knowledge leaking to service providers who might become future competitors (Pisano et al. 1988). Hence, knowledge transfer between home and foreign units is shown to be more efficient when a higher level of control (i.e., captive offshoring) is in place (Kogut and Zander 1992; Nieto and Rodríguez 2011).

\subsection{Cost Savings and Innovation Outcome of Global Sourcing}

In a hyper-competitive and global market, firms seek a competitive strategy that equips them with the ability to adapt quickly with the fast-changing demand and stay ahead of competitors. Global sourcing is shown to have a significant positive effect on the likelihood of firms to survive in globalized industries (Coucke and Sleuwaegen 2008) and firms' performance (Mol et al. 2005). This can be attributed to the positive relationship between global sourcing and firms' export and international sales (Bertrand 2011; Di Gregorio et al. 2009) as well as the positive effect of global sourcing on firms' innovation (e.g., Lin et al. 2017; Nieto and Rodríguez 2011).

The benefits of global sourcing on cost savings are driven by labor arbitrage as well as other costs such as benefits passed on from a service provider's economies of scale, upfront investment on foreign facilities. Cost savings, which derive from the difference in labor costs between developed and developing countries, are the main incentive for early adopters of global sourcing of business activities (Manning et al. 2008; Massini et al. 2010), especially for activities that do not require physical co-location (i.e., less coordination) and can be performed by highly-skilled workers in foreign locations. Global sourcing also provides firms with flexibility in their resource allocation as it allows firms to reap the benefits 
from offshore skills and talent without having to invest in setting up offshore facilities and recruiting offshore workforce.

Despite its benefits, the key drawback of global sourcing includes the hidden costs that are not perceived ex-ante and, hence, lead to undesirable outcomes including the failure to achieve the expected savings. The hidden costs are often associated with transaction costs resulting from the shift of ownership to an external provider as well as relocating and reconfiguring tasks and processes within the value chain (Larsen et al. 2012). An underestimation of costs associated with globally dispersed operations is, hence, identified as a major cause of firms' failure to achieve financial benefits of global value chains (Barthelemy 2001, 2003; Larsen et al. 2012). Too much reliance on global sourcing also exposes firms to the risk of bullwhip or whipsaw effect (Lee et al. 2015) and supply chain disruption causing by demand shock, political issues and trade war or black swan events (e.g., COVID-19 pandemic, 9-11).

The literature is filled with the mixed results suggesting both positive and negative relationship between global sourcing and firms' innovation. Global sourcing may lead to an increase in firm's innovation when it allows firms to gain access to knowledge, skill and technology not available in a home country, so-called home based augmenting (Kuemmerle 1999) or to exploit their knowledge and expertise in a new context of an offshore destination, so-called home based exploiting (Kuemmerle 1999). As suggested by the internationalization theory, access to knowledge and skills across national boundaries allows firms to take advantage of complementary location-specific advantages (Feinberg and Gupta 2004), which are not available or cannot be easily obtained in their home country (Doh 2005; Lewin et al. 2009a). Mukherjee et al. (2019) discussed global sourcing as a value creating tool for different types of knowledge outcomes. Increasing diversity in knowledge bases across locations further strengthens the benefit of global sourcing on firms' innovation (Narula and Zanfei 2005) as it provides firms with access to sources of knowledge and skills available in offshore locations in order to develop innovation to be exploited both at home and global markets.

On the other hand, global dispersion of value chain activities can pose a negative effect on firms' innovation outcome. Both geographical and cultural distance often creates a barrier in knowledge transfer and collaboration among globally dispersed teams, resulting in a decline in innovation outcome (Chen and Lin 2016; Lin et al. 2017). Furthermore, the transfer of ownership of activities to offshore service providers could lead to knowledge leakage and potential hollowing out effect, allowing service providers to become potential competitors in the future (Kotabe 1989).

It is essential that firms strategically balance the appropriate level of disaggregation, dispersion, and governance structure in order to maximize both cost savings and innovation outcome of global sourcing. We argue that the critical task here is to search for a global sourcing configuration that fits well with a firm's strategy, existing organizational structure, and routines. Drawing on the configurational concept of equifinality, we further argue that there may be more than one global sourcing configurations leading to high cost savings and high innovation from global sourcing activities. 


\section{Methods}

\subsection{Sample and Data Collection}

We examine the global sourcing configurations of 235 firms engaging in global sourcing of business service activities. These firms are drawn from the Offshoring Research Network (ORN) database. The ORN is a global research network of scholars from North America, Europe, and the Asia Pacific who study a phenomenon of global sourcing both from the global sourcing firms (i.e., client) and service provider perspective. ORN teams conducted annual surveys on organizations engaging global sourcing of business service activities from 2005 to 2011. The data set captures global sourcing of business service activities of firms across industries and countries, including fine-grained information (at project, function, and firm-level) about firms' global sourcing activities (including product design, engineering services, R\&D, IT, financial and accounting, human resources, legal services, contact centers, procurement, marketing and sales, and other administrative services), offshoring drivers, offshore locations, outcomes, and future plans. Given its fine grain level and comprehensiveness, ORN data has been used in a number of studies to investigate various aspects of global sourcing activities (Albertoni et al. 2017; Larsen et al. 2012; Lewin et al. 2009a; Pisani and Ricart 2018).

Firms included in the data set range from small with employees less than 500 to medium size (501-2000) and large corporate with employees more than 2000. Average firm employment is 37,489 employees, and median firm employment is 7000 employees. These firms have their headquarters located in various regions including 54.2\% in North America, 37.5\% in Europe, 7.5\% in Asia and Australia. They are also a good representative of firms across industries with, for example, $19.33 \%$ operating in finance and insurance, $14.24 \%$ operating in software and IT services and $12.13 \%$ operating in professional services. Table 2 provides details on the distribution of firms in the sample in terms of firm size, operating industry, and headquarters.

We also complement the ORN data with other secondary data sources to calculate geographical and cultural distance variables. The data on geographical distance (in kilometers) between a firm's headquarters and its offshoring units (either captive units or service providers) are collected from the GeoDist database. Cultural distance is measured using the Mahalanobis composite cultural index, which is a combination of Hofstede, Schwartz, and GLOBE cultural dimensions (see Beugelsdijk et al. 2017 for more details). Multiple data sources used in this study mitigate the issue of common method bias which is common in studies relying on a single source of data (Chang et al. 2010). 
Table 2 Characteristics of global sourcing firms included in the sample

\begin{tabular}{lc}
\hline & \% Firms \\
\hline Firm size & \\
Large & 35.0 \\
Midsize & 35.2 \\
Small & 29.7 \\
Headquarters location & \\
Asia & 3.4 \\
Europe & 37.5 \\
North America & 54.2 \\
South America & 0.4 \\
Australia and Oceania & 4.1 \\
Middle East & 0.4 \\
Operating industry & \\
Automotive & 2.6 \\
Biotech and Pharmaceutical & 3.5 \\
Consumer Goods & 3.3 \\
Finance and Insurance & 19.3 \\
Government and Defence & 1.9 \\
High Tech & 3.3 \\
Manufacturing & 9.9 \\
Other & 9.1 \\
Professional Services & 12.1 \\
Software and IT Services & 14.2 \\
Technical Services & 11.6 \\
Telecommunication & 5.5 \\
Transportation and warehousing & 3.5 \\
\hline
\end{tabular}

\subsection{Measures}

\subsubsection{Outcome Variables}

The outcome of global value chains can be measured in different forms. We refer to Schmeisser's (2013) classification of consequences of global sourcing as profit and sale-related outcome and resource and capability-related outcome. We, hence, measure two aspects of global sourcing outcome using ORN data: cost savings and innovation. Cost savings are measured by the average percentage of actual cost savings achieved from all global sourcing projects a firm engages in. Innovation captures the impact of global sourcing on a firm's knowledge and resources (e.g., qualified staffs) and new product and process. We constructed this composite measure using four ORN survey questions asking firms to rate (1) the level of their product innovation, (2) the level of process innovation outcome, (3) the better access to qualified personnel, and (4) the ability to source innovation outside firm boundaries. The responses are on a five-point Likert scale, ranging 
from strongly disagree (1) to strongly agree (5). The average of these four items is used to construct the measure of innovation outcome of a firm's global sourcing configuration.

\subsubsection{Disaggregation}

We measure the degree of disaggregation of a firm's value chain using two variables which represent the breadth and depth of disaggregation. First, we capture the breadth of disaggregation using the number of functions being offshored, which is a count of business service functions along a firm's value chain that are being sourced outside a home country. The ORN surveys capture 11 business service functions including engineering services, R\&D, product design, IT, contact centers, procurement, marketing and sales, finance and accounting, human resources, legal services, and other administrative functions. Hence, the minimum value of this variable is 1 (firms without any offshore functions are not included in the sample), and the maximum is 11 functions. Second, the depth of disaggregation is captured using the number of global sourcing projects, which is the sum of the number of global sourcing projects within each function. We note that the number of global sourcing projects is not necessarily correlated with the number of functions being offshored. For example, firm $A$ globally sources its contact center and R\&D function (number of functions being offshored $=2$ ). It engages in 5 offshore R\&D projects and 4 offshore contact center projects (number of global sourcing projects $=9$ ). On other hands, firm $B$ 's globally sourcing involves many more functions including $R \& D$, engineering services, legal services, finance and accounting, and human resources (number of functions being offshore $=5$ ) but it engages in only one offshore project in each function (number of global sourcing projects $=5$ ). In this study, we include both the number of functions being offshored and the number of global sourcing projects in the analysis to fully capture all aspects of the disaggregation of value chains.

\subsubsection{Dispersion}

Degree of dispersion measures the extent to which a firm globally disperses activities in its value chain. In this study, we examine dispersion both in terms of geographical distance and cultural distance. We draw on GeoDist database to calculate a geographical distance (in kilometer) between a firm's headquarters and its offshore locations. We then construct a degree of geographical dispersion by calculating Blau's index of diversity:

$$
S D=1-\sum_{i=1}^{N} p_{i}^{2}
$$

where $p$ is the proportion of a firm's geographical distance from its headquarters to offshore location $i$ to total distance to all offshore locations, and $N$ is the total number of a firm's offshore locations. Blau's index of diversity is a well-known measure 
of diversity and has been used in many studies examining organizational dispersion (e.g., Lahiri 2010).

Cultural distance between a firm's headquarters and its offshore locations are measured using the Mahalanobis composite cultural distance (Beugelsdijk et al. 2017), which has the benefit of combining the dimensions of three well-known cultural frameworks including Hofstede's six-dimensional cultural framework, Schwartz's seven-dimensional value framework, and GLOBE's nine-dimensional system of national cultural values. We applied Blau's index of diversity formula to calculate a firm's degree of cultural dispersion, where $p$ is now the proportion of a firm's cultural distance between its headquarters to offshore location $i$ to total cultural distance between a firm's headquarters and all offshore locations and $\mathrm{N}$ is the total number of a firm's offshore locations.

\subsubsection{Governance Mode (Organizational Dispersion)}

A choice on organizational dispersion-whether to outsource an activity to a third-party service provider or keep it as a captive operation-directly determines the level of control a firm has over its globally dispersed activities. When an activity is a captive offshoring operation, a firm retains its full ownership of activity and, hence, a high level of control. On the other hand, an offshore outsourcing operation involves a transfer of activity (and ownership) to a third-party service provider, resulting in a limited level of control over an activity. We measure the degree of organizational dispersion by calculating the ratio of global sourcing projects with captive governance mode to a total number of global sourcing projects. A high value of this captive ratio measure represents a high level of a firm's control over its global sourcing activities (i.e., lower degree of organizational dispersion). The minimum value of the captive ratio is 0 when every global sourcing project is outsourced to third-party service providers, and the maximum value of the captive ratio is 1 when every global sourcing project is captive operation (see Table 3 for a summary of the operationalization of measures included in the analysis).

\subsection{Statistical Method and Analysis}

To examine global sourcing configuration leading to high cost savings and high innovation outcome, we employed a set-theoretic approach based on fuzzy set Qualitative Comparative Analysis (fsQCA). fsQCA uses Boolean algebra to examine how cross-case patterns of causal conditions contribute to an outcome in question (Fiss 2007; Ragin 2006). It is a suitable approach for analyzing causal processes as it offers an understanding of how causal factors (i.e., independent variables in traditional regression analysis) combine to bring about a specific outcome of interest. More specifically, fsQCA explains causal patterns by examining members of the set of an outcome of interest (e.g., global sourcing with high cost savings) and identifying the combinations of factors associated with such outcome using Boolean algebra to reduce complex causal conditions into a reduced set of configurations. 


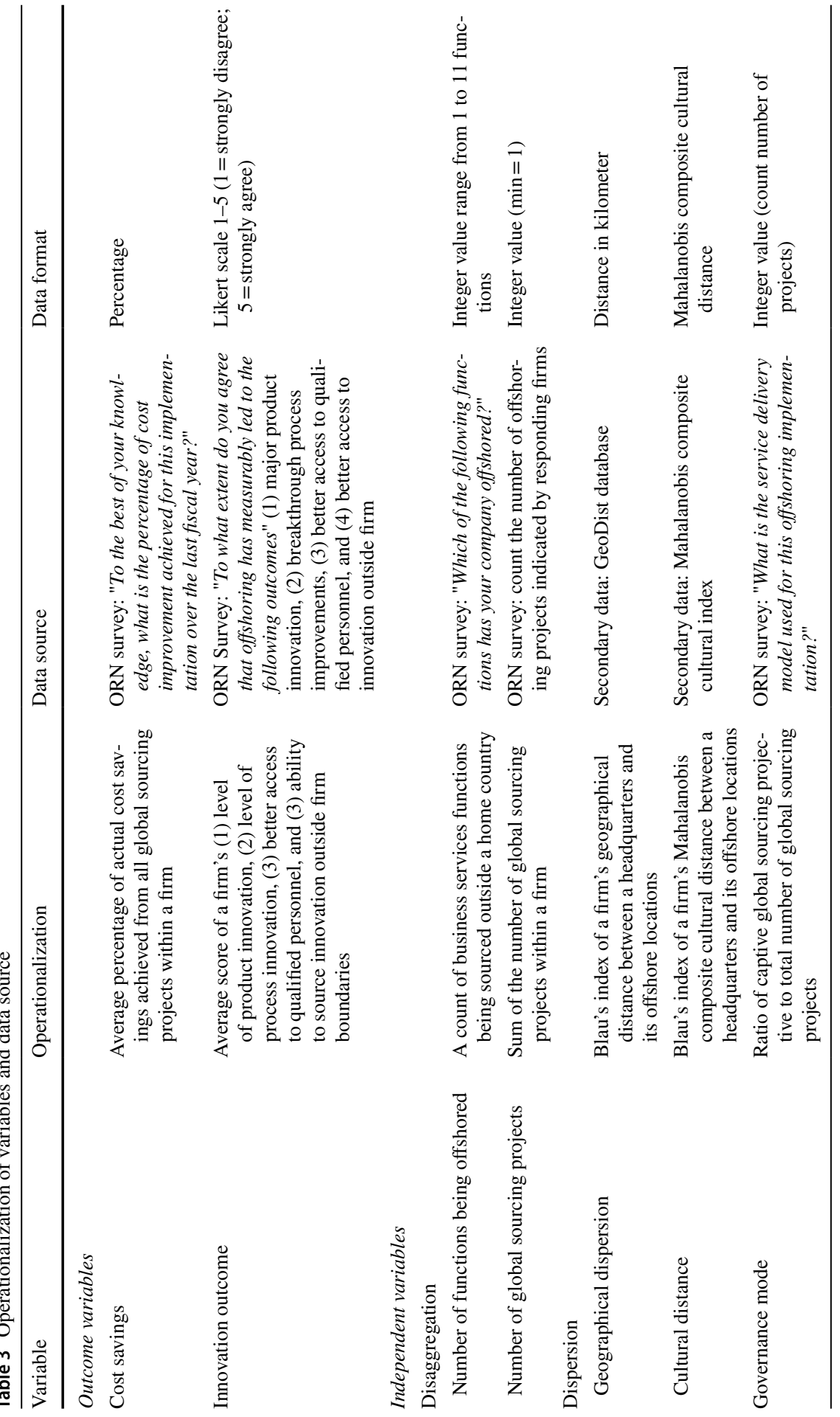


fsQCA approach differs from traditional symmetric analytical methods (e.g., regression) in several aspects. First, the key benefit of fsQCA lies in its ability to examine complex causal relationships and higher order interactions, which is often limited by the degrees of freedom in the regression analysis. Moving away from the "net effects" approach, fsQCA allows us to examine how the interdependent interplay of disaggregation, dispersion, and governance mode lead to differences in cost savings and innovation outcome of global sourcing activities. This is an important property of fsQCA, which make it an appropriate tool to study the relationships which causality is complex, and the traditional net effect approach is not able to accommodate such interdependencies and constrains theory development. Second, fsQCA also has the advantage over the traditional symmetric analysis methods as it is not restricted to any given probability distribution of the data (e.g., normal distribution) and accommodates asymmetric relationships across cases (Douglas et al. 2020; Fiss 2011). While symmetric analysis methods provide only a net-effects model based on the majority of samples and subsume minority cases, fsQCA captures the asymmetry of data relationships and, hence, serves as a good method for identifying these differences (Douglas et al. 2020). Third, fsQCA utilizes an inductive research method based on the principle of equifinality, assuming that multiple paths to a desired outcome can co-exist (i.e., more than one solution to the problem) (Fiss 2007). The equifinal characteristic of fsQCA is particularly beneficial to our study as it enables us to explore multiple global sourcing configurations leading to the high cost savings and innovation outcome without being constraints by the nature of regression-based analyses which are unable to take equifinality into account (Van De Ven and Drazin 1985). Shepherd and Suddaby (2016) suggest that "the approach can produce surprising findings as part of an abductive approach to theory building." Fainshmidt et al. (2020) strongly encourage international business scholars to adopt the configurational thinking in their studies of complex international business contexts and leverage the beneficial characteristics of fsQCA to overcome the common methodological issues (e.g., small sample size, multi-level variables) which cannot be addressed using traditional analytical techniques. Given the promised benefits, we have recently observed a rapid increase in the number of studies in international business (e.g., Fainshmidt et al. 2020; Verbeke et al. 2019; Witt and Jackson 2016), strategy (e.g., Fiss 2011; Misangyi and Acharya 2014; Schneider et al. 2010) and entrepreneurship (e.g., Stroe et al. 2018) utilizing this method to investigate the phenomena with complex causality. For example, Douglas et al. (2020) demonstrate how fsQCA complements the correlational methods and reveal complexity and heterogeneity of relationships in entrepreneurial phenomena. Greckhamer (2016) takes the configurational approach to reveal the fine-grained detail about casual asymmetry in CEO compensation.

The analysis starts with transforming all variables into sets and constructing a data matrix (so-called truth table) with $2^{k}$ rows, where $k$ is the number of causal (independent) variables. The truth table hence includes all possible combinations of causal variables (so-called configurations or solutions). The cases in the sample are then sorted into the rows of the truth table based on the value of their causal variables. The next step involves the reduction of the number of rows using two conditions: (1) the minimum number of cases required for a solution to be considered and 
(2) the minimum consistency level of a solution, where consistency is the degree to which cases correspond to the relationships expressed in a solution. In this study, we adopt the lowest acceptable consistency at 0.80 , which is well above the minimum recommended threshold of 0.75 (Ragin 2006, 2008), and the minimum solution frequency at 3, as commonly used in other studies (e.g., Fiss 2011). The final step is to apply Boolean algebra to the truth table rows to simplified combinations using Ragin's (2008) truth table algorithm, which is based on a counterfactual analysis of causal variables. In this study, we run the analysis using "fuzzy" package in Stata which is a suite of tools used to create, test and perform logical reductions on both fuzzy and dichotomous set-theoretic data (Longest and Vaisey 2008).

\section{Results}

\subsection{Global Sourcing Configurations for High Cost Savings}

Table 4 shows global sourcing configurations for high cost savings identified by fsQCA. To present the results of the analysis, we adopt Fiss' (2011) notation with a slight modification to simplify the presentation of the results. For each configuration, black circles $(\bullet)$ indicate the presence of a causal condition, white circles $(\bigcirc)$ indicate the absence or negation of a casual condition, and the blank cells indicate

Table 4 Global sourcing configurations leading to high cost savings

\begin{tabular}{|c|c|c|c|c|}
\hline \multirow[t]{3}{*}{ Configuration } & \multicolumn{4}{|c|}{$\begin{array}{l}\text { Configuration for high cost } \\
\text { savings }\end{array}$} \\
\hline & \multicolumn{2}{|c|}{$\begin{array}{l}\text { Efficiency } \\
\text { seeking }\end{array}$} & \multicolumn{2}{|c|}{$\begin{array}{l}\text { Global inte- } \\
\text { grator }\end{array}$} \\
\hline & $1 \mathrm{a}$ & $1 \mathrm{~b}$ & $2 \mathrm{a}$ & $2 b$ \\
\hline \multicolumn{5}{|l|}{ Disaggregation } \\
\hline Number of functions being offshored & $\bigcirc$ & $\bigcirc$ & $\bullet$ & $\bullet$ \\
\hline Number of offshoring projects & & $\bigcirc$ & $\bigcirc$ & \\
\hline \multicolumn{5}{|l|}{ Dispersion } \\
\hline Geographic dispersion & $\bullet$ & $\bullet$ & $\bullet$ & \\
\hline Cultural dispersion & $\bigcirc$ & $\bullet$ & & $\bullet$ \\
\hline \multicolumn{5}{|l|}{ Governance mode } \\
\hline Captive ratio & $\bullet$ & & $\bigcirc$ & $\bigcirc$ \\
\hline Raw coverage & 0.21 & 0.388 & 0.3 & 0.387 \\
\hline Unique coverage & 0.047 & 0.093 & 0.034 & 0.122 \\
\hline Solution consistency & 0.928 & 0.882 & 0.919 & 0.846 \\
\hline Total coverage & 0.632 & & & \\
\hline Overall consistency & 0.837 & & & \\
\hline
\end{tabular}

Black circles $(\bullet)$ indicate the presence of conditions. White circles (O) indicate the absence or negation of causal conditions. The blank cells indicate "don't care" 
irrelevant or 'don't care' condition that may be either present or absent from the causal combinations. As mentioned earlier, consistency measures the degree to which cases in the sample are consistent with the causal conditions expressed in each configuration. Coverage identifies how many cases with the expected outcome are represented by a particular set of causal conditions.

The solution table from the fuzzy set analysis shows four global sourcing configurations leading to high cost savings with consistency $\geq 0.80$. We note that the presence of four configurations leading to high cost savings points to equifinality of solutions-more than one possible configuration or path leading to the same outcome. All four configurations have high overall consistency $(0.837)$ and high coverage (0.632). Based on the overlapping characteristics of the configurations, we identify two main groups among these four global sourcing configurations leading to high cost savings.

The first group of firms employs the efficiency-seeking strategy in their global sourcing, which focuses on sourcing of a limited number of activities in their value chain (low degree of disaggregation) but from various locations across the globe (high geographical dispersion). More specifically, Configuration 1a and $1 \mathrm{~b}$ indicate that global sourcing configurations delivering high cost savings combine the absence of high degree of disaggregation (i.e., a small number of functions being offshored) and the presence of a high degree of geographical dispersion. Based on our in-depth review of global sourcing firms included in these configurations (e.g., types of activities being offshored), we found that firms with efficiency-seeking strategy tend to retain their core activities in-house while globally source their non-core activities from low-cost service providers who can get the task done at a lower cost and in a shorter period of time. This is consistent with the RBV argument suggesting that firms should focus their limited resources and capabilities on their core activities (Barney 1999; Quinn 2000). While Configuration 1a also requires the absence of cultural dispersion and the presence of high captive ratio (high level of control), Configuration $1 \mathrm{~b}$ focuses on the absence of a high number of sourcing projects (i.e., low degree of disaggregation) and the presence of high cultural dispersion. This difference suggests that firms can achieve a high cost savings with either high or low cultural dispersion in their global sourcing activities, but this choice needs to be strategically aligned with other factors, such as a level of control in this case. In summary, the efficiency-seeking strategy suggest that firms source only a limited set of activities in their value chain (mainly their non-core activities) but disperse their activities globally across locations where such activity can be performed more cost efficiently.

The second global sourcing strategy leading to high cost savings includes firms that source most activities in their value chain-retain an only small number of core activities-from third-party service providers located in highly dispersed locations around the world. Given the high degree of disaggregation and dispersion, we call this strategy a global integrator. As shown in Table 4, Configuration $2 \mathrm{a}$ and $2 \mathrm{~b}$ indicate that the presence of high number of offshore functions (i.e., high degree of disaggregation) together with the absence of high captive ratio (i.e., low level of control) also leads to high cost savings in global sourcing. In both Configuration $2 \mathrm{a}$ and $2 \mathrm{~b}$, high cost savings in global sourcing require either high geographical or cultural dispersion of value chain activities, but not both at the same time. More specifically, 
Configuration 2a requires the presence of geographical dispersion while Configuration $2 \mathrm{~b}$ requires the presence of cultural dispersion. A plausible explanation is that it could be overly challenging and complex for firms to manage offshore outsourcing (i.e., low level of control) that are high in both geographical and cultural dispersion. This issue of complexity is further highlighted in Configuration $2 \mathrm{a}$, which requires also the absence of a large number of offshoring projects to alleviate the cost and complexity of managing geographically dispersed teams (i.e., presence of high geographical dispersion).

Overall, the global integrator strategy suggests that to achieve high cost savings, firms focus on disaggregating their value chain into many discrete activities and sourcing these activities mainly from third-party service providers across the world who can perform an activity more efficiently and at a lower cost. However, given coordination issues and hidden costs of global sourcing (e.g., Larsen et al. 2012), firms adopting global integrator strategy are being conscious not to disperse their activities both geographically and culturally at the same time in order to keep the complexity of coordination across global teams at a manageable level.

\subsection{Global Sourcing Configurations for High Innovation}

Table 5 shows two global sourcing configurations for high innovation with a high overall solution consistency of 0.80 and overall solution coverage of 0.562 . While both configurations are different in their required causal conditions, the

Table 5 Global sourcing configurations leading to high innovation

\begin{tabular}{|c|c|c|}
\hline \multirow[b]{3}{*}{ Configuration } & \multicolumn{2}{|c|}{$\begin{array}{l}\text { Configuration for high } \\
\text { innovation }\end{array}$} \\
\hline & $\begin{array}{l}\text { Global innova- } \\
\text { tion outsourc- } \\
\text { ing }\end{array}$ & $\begin{array}{l}\text { Global } \\
\text { innovation } \\
\text { hub }\end{array}$ \\
\hline & 1 & 2 \\
\hline \multicolumn{3}{|l|}{ Disaggregation } \\
\hline Number of functions being offshored & $\bullet$ & $\bullet$ \\
\hline Number of offshoring projects & $\bullet$ & $\bullet$ \\
\hline \multicolumn{3}{|l|}{ Dispersion } \\
\hline Geographic dispersion & $\bullet$ & \\
\hline \multicolumn{3}{|l|}{ Governance mode } \\
\hline Captive ratio & $\bigcirc$ & $\bullet$ \\
\hline Raw coverage & 0.497 & 0.156 \\
\hline Unique coverage & 0.406 & 0.066 \\
\hline Solution consistency & 0.8 & 0.802 \\
\hline Total coverage & 0.562 & \\
\hline Overall consistency & 0.8 & \\
\hline
\end{tabular}

Black circles $(\bullet)$ indicate the presence of conditions. White circles (O) indicate the absence or negation of causal conditions. The blank cells indicate "don't care" 
common condition between them is the presence of high degree of disaggregation, both in terms of the number of functions being offshored and the number of offshoring projects. This implies that the more finely a firm slices their value chain and source globally, the more likely innovation and cross-pollination of knowledge will occur, which is in line with arguments suggested in the open innovation literature (Chesbrough 2004).

The first group of firms pursues what we call a global innovation outsourcing strategy, which relies heavily on an outsourcing of highly disaggregated and highly dispersed activities in their value chains. More specifically, Configuration 1 indicates that to drive high innovation in global sourcing the presence of highly disaggregated value chain should be accompanied with the presence of geographical dispersion, absence of cultural dispersion and absence of the high level of control. Despite a clear emphasis on high disaggregation and geographical dispersion, global innovation outsourcing firms deem to be mindful of keeping cultural dispersion at the minimum as high cultural distance is shown to be detrimental to knowledge exchange and innovation (e.g., Chua et al. 2015). Further in-depth analysis on firms included in this configuration suggests that most firms engaging in global innovation outsourcing strategy send their activities to the third-party service providers located in various continents in an attempt to tap into knowledge base and talent pools available in various locations. This allows them to generate additional new ideas and innovation compared to relying solely on the internal and domestic knowledge and skills. In summary, the global innovation outsourcing strategy suggests that firms leverage the breadth of external knowledge sourced from third-party service providers located in various locations to enhance their innovation.

Configuration 2 depicts a different path to high innovation performance in global sourcing. In contrast to the global innovation outsourcing strategy, Configuration 2 represents the strategy, we refer to as a global innovation hub, which focuses on retaining the control over globally disaggregated activities. More specifically, firms included in Configuration 2 achieve high innovation outcome through the presence of highly dispersed value chain combined with the presence of high cultural dispersion and high level of control. Firms exhibiting a global innovation hub strategy leverage on the balance between maximizing creative idea generation through cultural diversity (Leiponen and Helfat 2010) and ensuring value capture through a captive governance model (Lin et al. 2016; Roza et al. 2011).

Taken together, the findings from both configurations suggest that disaggregation of value chains should be done with care and that the sufficient level of control is a critical factor in global sourcing strategy to ensure that firms are able to capture innovation and value created in globally dispersed activities and bring it back into firms. In particular, global innovation outsourcing strategy illustrates that when the disaggregation of value chain activities involves only high geographical dispersion but not cultural dispersion, firms may achieve high innovation outcome through an outsourcing to third-party service providers. Nevertheless, if global sourcing activities involve a high degree of cultural dispersion, as in global innovation hub strategy, which requires more time and effort in 
cross-cultural coordination and communication, a tighter control through captive operations is necessary for firms to be able to capture innovation and value created in global sourcing activities.

\section{Discussion and Conclusion}

Although the phenomenon of global sourcing has been studied extensively in international business and supply chain research, the understanding of global sourcing strategy leading to high performance remains unfulfilled (Kotabe and Murray 2017; Leiblein et al. 2002). In this study, we argue that the key challenge in examining the global sourcing configurations leading to high performance lies in the complex casual conditions and equifinality of these relationships. We overcome this challenge by adopting the configurational approach to examine the combinations of casual conditions leading to high cost savings and those leading to high innovation outcome in global sourcing activities.

Our findings suggest that there are no universal global sourcing configurations for achieving both high cost savings and high innovation. Instead, firms need to first clearly identify the expected outcome of their global sourcing activities and design their global sourcing configuration that aligns with the expectation. This emphasizes the importance of global sourcing strategy and planning, which is often overlooked at the corporate level. Studies show that in several cases firms take on global sourcing as an ad-hoc decision in response to their operational needs (e.g., cost savings, access to required skill, reduce time to market) without incorporating global sourcing as part of the corporate strategy (Massini et al. 2010). The lack of global sourcing strategy is shown to be one of the key reasons of the failure to achieve the expected outcome in global sourcing activities reported by a number of firms (Heijmen et al. 2009; Massini et al. 2010). Hence, we encourage firms to carefully craft their global sourcing strategy to guide their global sourcing decisions and to ensure that their choices of global sourcing align with the expected outcome.

Our study also highlights the need for firms to strategically manage and align their choices on disaggregation, dispersion, and governance mode of the global sourcing in order to achieve the optimal outcomes (see Table 6 for a summary of global sourcing configurations based on our findings). As the results illustrate, the outcome of global sourcing does not depend on the net effect of a particular factor but relies heavily on the complex combination of disaggregation, dispersion and governance mode of firms' global sourcing activities. While most firms focus on potential value creation (through disaggregation and dispersion of activities) in their global sourcing decisions, they often fail to take into account value capture mechanism (i.e., governance structure or level of control over sourcing activities). It is crucial that firms take a holistic view and consider both value creation and value capture in their sourcing decisions. This resonates well with the call for global sourcing scholars to pay more attention to the important role of global sourcing strategy (Massini et al. 2010) in both creating the expected value through disaggregation and dispersion of activities and capturing such value through an appropriate governance structure. 


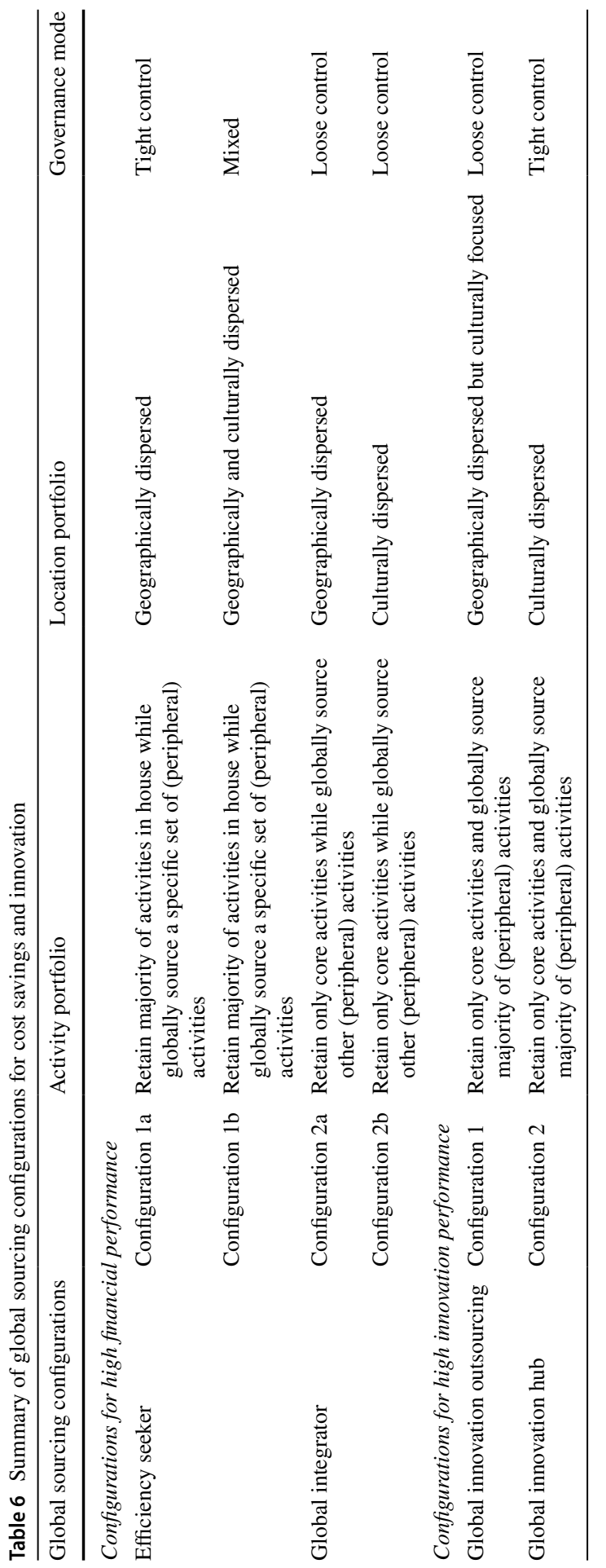




\subsection{Theoretical Implications}

This research makes three contributions to the literature on global sourcing. First, we extend Kedia and Mukherjee's (2009) DLE framework and Contractor et al.'s (2010) seminal work by providing a better understanding on how the combination of disaggregation, geographical and organizational dispersion of global sourcing configuration leads to differences in cost savings and innovation outcome of global sourcing activities. To understand these complex causal relationships, we adopt the configurational approach to evaluate global sourcing configurations leading to high cost savings and those leading to high innovation. We are among the first attempts to examine the combined effect of all three components of global sourcing configuration on the performance of global sourcing activities. In doing so, this study provides a more nuanced and realistic picture of the causal mechanism underlying high performing global sourcing. Our findings suggest that firms should clearly identify what they aim to achieve from their global sourcing activities and design their global sourcing strategy accordingly as there is no one-size-fits-all strategy. More importantly, the findings also reveal the equifinality of the global sourcing configurations, suggesting that firms are not restricted to a single 'template' on how to design their global sourcing configuration but can adopt one that suits their context as there exists more than one possible configurations leading to the same outcome. Our findings also contribute to the theoretical tension in global sourcing research and extend an understanding of heterogeneity in the performance of global sourcing activities. We have shown that the performance of global sourcing is determined not only by a single component of global sourcing configuration (disaggregation, dispersion, or governance structure), but also the interaction between these components. Accordingly, future research should take into account the interplay among disaggregation, dispersion and governance structure to accurately understand global sourcing activities and their outcome.

Second, our study identifies an alternative view of distance in globally dispersed activities. While research in international business focuses exclusively on the effect of various types of distance (e.g., geographical, institutional, cultural distance) on MNC performance, we show that the effect of the distance needed to be considered in conjunction with other elements such as level of control when examining its relationship with performance. We, therefore, argue that the inconsistent findings on the effect of distance on multinational firm's performance in the literature can be attributed to the fact that we focus exclusively on the net effect of distance and fail to consider the combined effect of distance with other relevant factors. This further demonstrates that the configurational theory and analysis could be a promising foundation to address the research questions that have not been conclusively answered on this topic.

Third, we advance the understanding of the role of governance mode on the outcome of global sourcing activities. Through the configurational approach, we are able to provide a salient explanation of how the appropriate level of control is contingent on other components in the global sourcing configuration. Global innovation outsourcing and global innovation hub strategy suggest that the level of control is particularly important when innovation, which is often more tacit in nature as well 
as difficult to identify ex-ante, is expected in global sourcing activities. This finding is consistent with Lumineau and Quelin's (2012) argument on the importance of value capture mechanism in a complicated relationship which the allocation of rents is ambiguous (see also Lin et al. 2016). Given the equifinality in our findings, we suggest that future studies consider the effect of a governance mode not by itself but in combination with the degree of disaggregation and dispersion in order to determine the global sourcing configuration that yields the optimal expected outcome.

\subsection{Managerial Implications}

The theoretical contributions from our study also raise considerable practical concerns, primarily the need for managers and firms to shift from an independent evaluation of each component (i.e., disaggregation, dispersion, and governance structure) in the global sourcing configuration to a holistic view of the combined effect of these components. This change suggests that firms and managers consider a more complete and holistic view when managing their global sourcing portfolio. While firms traditionally manage each global sourcing project separately and mostly at the operational level, our study illustrates the benefits of integrating global sourcing strategy into the corporate strategy. As the findings show, a carefully considered combination of degree of disaggregation, dispersion, and governance mode will enable firms to achieve the expected outcome from their global sourcing.

We further suggest that a clear expectation together with a global sourcing strategy that aligns with the expectation assists firms in making better and more coherent decisions on their global sourcing portfolio as a whole. Studies have shown that in many cases firms utilize global sourcing as a quick fix to their operational issues (Heijmen et al. 2009), causing a separate and uncoordinated set of activities dispersing across teams and countries. Based on the findings, we recommend that firms take a holistic view when making decisions on disaggregation, geographical and organizational dispersion of their global sourcing activities.

\subsection{Limitations and Future Research Directions}

In addition to the contributions made to the global sourcing literature as well as to firms and managers engaging in global sourcing, a few limitations have to be noted. The first limitation concerns our selection to focus on Contractor et al.'s (2010) key components - disaggregation, dispersion, and governance structure-of global sourcing configurations. Despite our attempt to incorporate as many components to create a complete view of global sourcing configurations, we have to make a tradeoff between the completeness of the model and the complexity of configurations. We focus our study on the three critical factors which have found to have significant effects on cost savings and innovation outcomes of global value chains (Contractor et al. 2010; Lin et al. 2017; Rodríguez and Nieto 2016). However, we recognize the importance of firms' ability to reintegrate their globally dispersed activities back into their value chain (Contractor et al. 2010) and encourage scholars to examine the effect of reintegration on the outcome of global sourcing in their future research. 
A second limitation refers to the use of a subjective measure on innovation outcome based on the self-reported innovation outcome of global sourcing activities from the ORN survey. We acknowledge that innovation can be measured using other sources of data, such as new products and services developed as part of the global sourcing activities, number of patents. However, owing to the limitations of the data, we are unable to cross-validate the self-reported innovation outcome with other measures. Hence, we encourage future researchers to improve our study by testing the relationships using other objective measures of innovation outcome.

The third limitation is associated with an inclusion of global sourcing firms from various locations and industries and with different levels of global sourcing experience in our study. We acknowledge that there may exist the heterogeneity in the effect of disaggregation, dispersion and governance structure on cost savings and innovation outcome of global sourcing. Hence, we also conducted sub-sample analyses on firms operating in high-tech versus non-high-tech industry. The results, however, do not show interesting or significant differences because the global sourcing configurations leading to high cost savings and high innovation in each industry group are consistent with the findings from the overall sample. It is our conscious decision to examine the global sourcing configurations based on the overall population and, hence, differences between locations, industries, firm size, or levels of experience are beyond the scope of our study. We argue that the issue of heterogeneity in global sourcing strategy requires a dedicate study which does not merely examine whether the heterogeneity exists but also provides an explanation of what determines such heterogeneity. To do so, such research need a well-designed data collection specifically to examine the issue of heterogeneity (e.g., sufficient sample size across firm location, size and industries). We believe the topic of heterogeneity in global sourcing strategy will be a great opportunity for future research.

\section{References}

Albertoni, F., Elia, S., Massini, S., \& Piscitello, L. (2017). The reshoring of business services: Reaction to failure or persistent strategy? Journal of World Business, 52(3), 417-430.

Ambos, B., \& Ambos, T. C. (2011). Meeting the challenge of offshoring R\&D: An examination of firmand location-specific factors. R\&D Management, 41(2), 107-119.

Ambos, T. C., \& Ambos, B. (2009). The impact of distance on knowledge transfer effectiveness in multinational corporations. Journal of International Management, 15(1), 1-14.

Apte, U. M., \& Mason, R. O. (1995). Global disaggregation of information-intensive services. Management Science, 41(7), 1250-1263.

Asmussen, C. G., Larsen, M. M., \& Pedersen, T. (2016). Organizational adaptation in offshoring: The relative performance of home- and host-based learning strategies. Organization Science, 27(4), 911-928.

Baldwin, C. Y., \& Clark, K. (1997). Managing in an age of modularity. Harvard business Review, 75, 84-93.

Baldwin, C. Y., \& Clark, K. B. (2000). Design rules: The power of modularity. Cambridge: MIT Press.

Barney, J. B. (1999). How a firm's capabilities affect boundary decisions. Sloan Management Review, 40(3), 137-145.

Barthelemy, J. (2001). The hidden costs of IT outsourcing. MIT Sloan Management Review, 42(3), 60-69. 
Barthelemy, J. (2003). The seven deadly sins of outsourcing. The Academy of Management Executive, $17(2), 87-98$.

Bertrand, O. (2011). What goes around, comes around: Effects of offshore outsourcing on the export performance of firms. Journal of International Business Studies, 42(2), 334-344.

Beugelsdijk, S., Kostova, T., \& Roth, K. (2017). An overview of Hofstede-inspired country-level culture research in international business since 2006. Journal of International Business Studies, 48(1), $30-47$.

Boschma, R. (2005). Proximity and innovation: A critical assessment. Regional studies, 39(1), 61-74.

Caniato, F., Elia, S., Luzzini, D., Piscitello, L., \& Ronchi, S. (2015). Location drivers, governance model and performance in service offshoring. International Journal of Production Economics, 163, 189-199.

Carmel, E. (2006). Building your information systems from the other side of the world: How Infosys manages time zone differences. MIS Quarterly Executive, 5(1), 43-53.

Carmel, E., Espinosa, J. A., \& Dubinsky, Y. (2010). "Follow the sun” workflow in global software development. Journal of Management Information Systems, 27(1), 17-38.

Chang, S.-J., Van Witteloostuijn, A., \& Eden, L. (2010). From the editors: Common method variance in international business research. Journal of International Business Studies, 41(2), 178-184.

Chen, S., \& Lin, N. (2016). Global dispersion of offshore service providers: An information processing perspective. Journal of Knowledge Management, 20(5), 1065-1082.

Chen, S., \& Lin, N. (2018). The effect of inter- and intra-organizational distances on success of offshored outsourced innovation: A configurational approach. Journal of Business Research, 103(C), 519-529.

Chesbrough, H. (2004). Manageing open innovation. Research Technology Management, 47(1), $23-26$.

Chua, R. Y. J., Roth, Y., \& Lemoine, J. F. (2015). The impact of culture on creativity: How cultural tightness and cultural distance affect global innovation crowdsourcing work. Administrative Science Quarterly, 60(2), 189-227.

Cohen, M. A., \& Mallik, S. (1997). Global supply chains: Research and applications. Production and Operations Management, 6(3), 193-210.

Contractor, F. J., Kumar, V., Kundu, S. K., \& Pedersen, T. (2010). Reconceptualizing the firm in a world of outsourcing and offshoring: The organizational and geographical relocation of high-value company functions. Journal of Management Studies, 47(8), 1417-1433.

Coucke, K., \& Sleuwaegen, L. (2008). Offshoring as a survival strategy: Evidence from manufacturing firms in Belgium. Journal of International Business Studies, 39(8), 1261-1277.

Di Gregorio, D., Musteen, M., \& Thomas, D. E. (2009). Offshore outsourcing as a source of international competitiveness for SMEs. Journal of International Business Studies, 40(6), 969-988.

Dibbern, J., Winkler, J., \& Heinzl, A. (2008). Explaining variations in client extra costs between software projects offshored to India. MIS Quarterly, 32(2), 333-366.

Doh, J. P. (2005). Offshore outsourcing: Implications for international business and strategic management theory and practice. Journal of Management Studies, 42(3), 695-704.

Douglas, E. J., Shepherd, D. A., \& Prentice, C. (2020). Using fuzzy-set qualitative comparative analysis for a finer-grained understanding of entrepreneurship. Journal of Business Venturing, 35, 1. https:// doi.org/10.1016/j.jbusvent.2019.105970

Dunning, J. H. (1980). Toward an eclectic theory of international production: Some empirical tests. Journal of International Business Studies, 11(1), 9-31.

Dunning, J. H. (1993). Multinational enterprises and the global economy. Reading: Edward Elgar.

Elia, S., Caniato, F., Luzzini, D., \& Piscitello, L. (2014). Governance choice in global sourcing of services: The impact on service quality and cost saving performance. Global Strategy Journal, 4(3), 181-199.

Ellram, L. M., Tate, W. L., \& Billington, C. (2008). Offshore outsourcing of professional services: A transaction cost economics perspective. Journal of Operations Management, 26(2), 148-163.

Espino-Rodríguez, T. F., \& Padrón-Robaina, V. (2006). A review of outsourcing from the resource based view of the firm. International Journal of Management Reviews, 8(1), 49-70.

Fainshmidt, S., Witt, M. A., Aguilera, R. V., \& Verbeke, A. (2020). The contributions of qualitative comparative analysis (QCA) to international business research. Journal of International Business Studies, 51(4), 455-466.

Feinberg, S. E., \& Gupta, A. K. (2004). Knowledge spillovers and the assignment of R\&D responsibilities to foreign subsidiaries. Strategic Management Journal, 25(8-9), 823-845. 
Fiss, P. C. (2007). A set-theoretic approach to organizational configurations. Academy of Management Review, 32(4), 1180-1198.

Fiss, P. C. (2011). Building better causal theories: A fuzzy set approach to typologies in organization research. Academy of Management Journal, 54(2), 393-420.

Fuchs, E., \& Kirchain, R. (2010). Design for location? The impact of manufacturing offshore on technology competitiveness in the optoelectronics industry. Management Science, 56(120), 2323-2349.

Gereffi, G., Humphrey, J., \& Sturgeon, T. (2005). The governance of global value chains. Review of International Political Economy, 12(1), 78-104.

Gilley, K. M., \& Rasheed, A. (2000). Making more by doing less: An analysis of outsourcing and its effects on firm performance. Journal of Management, 26(4), 763-790.

Greckhamer, T. (2016). CEO compensation in relation to worker compensation across countries: The configurational impact of country-level institutions. Strategic Management Journal, 37(4), 793-815.

Gualandris, J., Golini, R., \& Kalchschmidt, M. (2014). Do supply management and global sourcing matter for firm sustainability performance?: An international study. Supply Chain Management, 19(3), $258-274$.

Hansen, M. T., Nohria, N., \& Tierney, T. (1999). What's your strategy for managing knowledge? Harvard Business Review, 77(2), 106-116.

Heijmen, T., Lewin, A. Y., Manning, S., Perm-Ajchariyawong, N., \& Russel, J. (2009). Offshoring Reaches the C-Suite. New York.

Hofstede, G. (1983). The cultural relativity of organizational practices and theories. Journal of International Business Studies, 14(2), 75-89.

Holcomb, T. R., \& Hitt, M. A. (2007). Toward a model of strategic outsourcing. Journal of Operations Management, 25(2), 464-481.

Hutzschenreuter, T., Kleindienst, I., \& Lange, S. (2014). Added psychic distance stimuli and MNE performance: Performance effects of added cultural, governance, geographic, and economic distance in MNEs' international expansion. Journal of International Management, 20(1), 38-54.

Hutzschenreuter, T., Lewin, A. Y., \& Dresel, S. (2011a). Time to success in offshoring business processes a multi level analysis. Management International Review, 51(1), 65-92.

Hutzschenreuter, T., Lewin, A. Y., \& Dresel, S. (2011b). Governance modes for offshoring activities: A comparison of US and German firms. International Business Review, 20(3), 291-313.

Hymer, S. H. (1976). International operations of national firms. MIT press.

Jacobides, M. G. (2005). Industry change through vertical disintegration: How and why markets emerged in mortgage banking. Academy of Management Journal, 48(3), 465-498.

Jha, S. K., Dhanaraj, C., \& Krishnan, R. T. (2018). From arbitrage to global innovation: Evolution of multinational R\&D in emerging markets. Management International Review, 58(4), 633-661.

Johanson, J., \& Vahlne, J. E. (1977). The internationalization process of the firm: A model of knowledge development and increasing foreign market commitments. Journal of International Business Studies, 8(1), 25-34.

Kearney, A. T. (2014). Global Services Location Index-A.T. Kearney. Global Services Location Index 2014.

Kedia, B. L., \& Mukherjee, D. (2009). Understanding offshoring: A research framework based on disintegration, location and externalization advantages. Journal of World Business, 44(3), 250-261.

Kogut, B. (1985). Designing global strategies: Comparative and competitive value-added chains. Sloan Management Review, 26(4), 15.

Kogut, B., \& Zander, U. (1992). Knowledge of firm, combinative capabilities, and the replication of technology. Organization Science, 3(3), 383-397.

Kotabe, M. (1989). "Hollowing-out" of US multinationals and their global competitiveness: An intrafirm perspective. Journal of Business Research, 19(1), 1-15.

Kotabe, M., \& Murray, J. Y. (2004). Global sourcing strategy and sustainable competitive advantage. Industrial Marketing Management, 33(1), 7-14.

Kotabe, M., \& Murray, J. Y., et al. (2017). Global sourcing strategy: An evolution in global production and sourcing rationalization. In L. C. Leonidou (Ed.), Advances in global marketing (pp. 265-384). Cham: Springer.

Kuemmerle, W. (1999). The drivers of foreign direct investment into research and development: An empirical investigation. Journal of International Business Studies, 30(1), 1-24.

Lahiri, N. (2010). Geographic distribution of R\&D activity: How does it affect innovation quality? Academy of Management Journal, 53(5), 1194-1209. 
Lahiri, S., Kedia, B. L., \& Mukherjee, D. (2012). The impact of management capability on the resourceperformance linkage: Examining Indian outsourcing providers. Journal of World Business, 47(1), $145-155$.

Lampert, C. M., \& Kim, M. (2019). Going far to go further: Offshoring, exploration, and R\&D performance. Journal of Business Research, 103(C), 376-386.

Larsen, M. M. (2016). Failing to estimate the costs of offshoring: A study on process performance. International Business Review, 25(1), 307-318.

Larsen, M. M., Manning, S., \& Pedersen, T. (2012). Uncovering the hidden costs of offshoring: The interplay of complexity, organizational design, and experience. Strategic Management Journal, 34(5), 533-552.

Lee, H. L., Padmanabhan, V., \& Whang, S. (2015). The bullwhip effect in supply chains. IEEE Engineering Management Review, 38(3), 93-102.

Leiblein, M. J., Reuer, J. J., \& Dalsace, F. (2002). Do make or buy decisions matter? The influence of organizational governance on technological performance. Strategic Management Journal, 23(9), $817-833$.

Leiponen, A., \& Helfat, C. E. (2010). Innovation objectives, knowledge sources, and the benefits of breadth. Strategic Management Journal, 31(2), 224-236.

Levy, D. L. (1995). International sourcing and supply chain stability. Journal of International Business Studies, 26(2), 343-360.

Lewin, A. Y., Massini, S., \& Peeters, C. (2009). Why are companies offshoring innovation? The emerging global race for talent. Journal of International Business Studies, 40(6), 901-925.

Lewin, A. Y., \& Peeters, C. (2006). Offshoring work: Business hype or the onset of fundamental transformation? Long Range Planning, 39(3), 221-239.

Lewin, A. Y., Perm-Ajchariyawong, N., Sappenfield, D., \& Aird, C. (2009). Is the global outsourcing industry in for a no-holds-barred competition? ORN Service Provider Survey Report.

Lin, N., Devinney, T. M., \& Holcomb, T. R. (2016). Examining managerial preferences and choices: The role of value creation and value appropriation drivers in strategic outsourcing. Long Range Planning, 49(6), 706-722.

Lin, N., Tan, H., \& Chen, S. (2017). Global offshoring portfolio diversity and performance implications. International Journal of Physical Distribution and Logistics Management, 47(2-3), 114-136.

Lo, Y. J., \& Hung, T. M. (2015). Structure offshoring and returns on offshoring. Asia Pacific Journal of Management, 32(2), 443-479.

Longest, K. C., \& Vaisey, S. (2008). Fuzzy: A program for performing qualitative comparative analyses (QCA) in Stata. Stata Journal, 8(1), 79-104.

Lumineau, F., \& Quélin, B. V. (2012). An empirical investigation of interorganizational opportunism and contracting mechanisms. Strategic Organization, 10(1), 55-84.

Manning, S., Massini, S., \& Lewin, A. Y. (2008). A dynamic perspective on next-generation offshoring: The global sourcing of science and engineering talent. Academy of Management Perspectives, 22(3), 35-54.

Mihalache, M., \& Mihalache, O. R. (2020). What is offshoring management capability and how do organizations develop it? A study of Dutch IT service providers. Management International Review, 60(1), 37-67.

Massini, S., Perm-Ajchariyawong, N., \& Lewin, A. Y. (2010). Role of corporate-wide offshoring strategy on offshoring driveres, risks and performance. Industry and Innovation, 17(4), 337-371.

Mauri, A. J., \& Neiva de Figueiredo, J. (2012). Strategic patterns of internationalization and performance variability: Effects of US-based MNC cross-border dispersion, integration, and outsourcing. Journal of International Management, 18(1), 38-51.

Mazzola, E., Bruccoleri, M., \& Perrone, G. (2019). The curvilinear effect of manufacturing outsourcing and captive-offshoring on firms' innovation: The role of temporal endurance. International Journal of Production Economics, 211(C), 197-210.

Misangyi, V. F., \& Acharya, A. G. (2014). Substitutes or complements? A configurational examination of corporate governance mechanisms. Academy of Management Journal, 57(6), 1681-1705.

Mol, M. J., Van Tulder, R. J. M., \& Beije, P. R. (2005). Antecedents and performance consequences of international outsourcing. International Business Review, 14(5), 599-617.

Mudambi, R. (2008). Location, control and innovation in knowledge-intensive industries. Journal of Economic Geography, 8(5), 699-725.

Mudambi, R., \& Venzin, M. (2010). The strategic nexus of offshoring and outsourcing decisions. Journal of Management Studies, 47(8), 1510-1533. 
Mukherjee, D., Gaur, A. S., \& Datta, A. (2013). Creating value through offshore outsourcing: An integrative framework. Journal of International Management, 19(4), 377-389.

Mukherjee, D., \& Kedia, B. L. (2012). Offshoring and MNC strategy. In A. Verbeke \& H. Merchant (Eds.), Handbook of research on international strategic management (pp. 413-429). Cheltenham: Edward Elgar.

Mukherjee, D., Lahiri, S., Ash, S. R., \& Gaur, A. S. (2019). Search motives, local embeddedness, and knowledge outcomes in offshoring. Journal of Business Research, 103(October), 365-375.

Murray, J. Y., \& Kotabe, M. (1999). Sourcing strategies of US service companies: A modified transaction-cost analysis. Strategic Management Journal, 20(9), 791-809.

Murray, J. Y., Kotabe, M., \& Wildt, A. R. (1995). Strategic and financial performance implications of global sourcing strategy: A contigency analysis. Journal of International Business Studies, 26(1), 181-202.

Narula, R., \& Zanfei, A. (2005). Globalisation of innovation: The role of multinational enterprises. In J. Fagerberg, D. Mowery, \& R. R. Nelson (Eds.), Handbook of innovation (pp. 318-347). New York: Oxford University Press.

Nieto, M. J., \& Rodríguez, A. (2011). Offshoring of R\&D: Looking abroad to improve innovation performance. Journal of International Business Studies, 42(3), 345-361.

Peng, M. W. (2001). The resource-based view and international business. Journal of Management, 27(6), 803-829.

Pisani, N., \& Ricart, J. E. (2016). Offshoring of services: A review of the literature and organizing framework. Management International Review, 56(3), 385-424.

Pisani, N., \& Ricart, J. E. (2018). Offshoring innovation to emerging countries: The effects of IP protection and cultural differences on firms' decision to augment versus exploit home-base-knowledge. Management International Review, 58(6), 871-909.

Pisano, G. P., Russo, M. V., \& Teece, D. J. (1988). Joint ventures and collaborative arrangements in the telecommunications equipment industry. International Collaborative Ventures in US Manufacturing, 20, 23-70.

Porter, M. E. (1985). Competitive advantage. Creating and sustaining superior performance. New York: The Free Press.

Prahalad, C. K., \& Hamel, G. (1990). The core competence of the corporation. Harvard Business Review, 68(3), 79-91.

Quinn, J. B. (2000). Outsourcing innovation: The new engine of growth. Sloan Management Review, 41(4), 13-28.

Quinn, J. B., \& Hilmer, F. G. (1994). Strategic outsourcing. The McKinsey Quarterly, 1(4), 43-55.

Ragin, C. (2006). Set relations in social research: Evaluating their consistency and coverage. Political Analysis, 14(3), 291-310.

Ragin, C. (2008). Redisigning social inquiry: Fuzzy sets and beyond. Chicago: University of Chicago Press.

Richardson, G. B. (1972). The organization of industry. Economic Journal, 82(327), 883-896.

Rodríguez, A., \& Nieto, M. J. (2016). Does R\&D offshoring lead to SME growth? Different governance modes and the mediating role of innovation. Strategic Management Journal, 37(8), 1734-1753.

Rosenbusch, N., Gusenbauer, M., Hatak, I., Fink, M., \& Meyer, K. E. (2019). Innovation offshoring, institutional context and innovation performance: A meta-analysis. Journal of Management Studies, 56(1), 203-233.

Roy, S., \& Sivakumar, K. (2011). Managing intellectual property in global outsourcing for innovation generation. Journal of Product Innovation Management, 28(1), 48-62.

Roza, M., Van den Bosch, F. A. J., \& Volberda, H. W. (2011). Offshoring strategy: Motives, functions, locations, and governance modes of small, medium-sized and large firms. International Business Review, 20(3), 314-323.

Sako, M. (2003). Modularity and outsourcing. In A. Davies \& M. Hobday (Eds.), The business of systems integration (pp. 229-253). Oxford: Oxford University Press.

Sako, M. (2006). Outsourcing and offshoring: Implications for productivity of business services. Oxford Review of Economic Policy, 22, 499-512.

Schilling, M. A. (2000). Toward a general modular systems theory and its application to interfirm product modularity. Academy of Management Review, 25(2), 312-334.

Schilling, M. A., \& Steensma, H. K. (2001). The use of modular organizational forms: Analysis. The Academy of Management Journal, 44(6), 1149-1168. 
Schleimer, S., \& Riege, A. (2009). Knowledge transfer between globally dispersed units at BMW. Journal of Knowledge Management, 13(1), 27-41.

Schmeisser, B. (2013). A systematic review of literature on offshoring of value chain activities. Journal of International Management, 19(4), 390-406.

Schneider, C. O., Bremen, P., Schönsleben, P., \& Alard, R. (2013). Transaction cost economics in global sourcing: Assessing regional differences and implications for performance. International Journal of Production Economics, 141(1), 243-254.

Schneider, M. R., Schulze-Bentrop, C., \& Paunescu, M. (2010). Mapping the institutional capital of hightech firms: A fuzzy-set analysis of capitalist variety and export performance. Journal of International Business Studies, 41(2), 246-266.

Shepherd, D. A., \& Suddaby, R. (2016). Theory building: A review and integration. Journal of Management, 43(1), 59-86.

Singh, N., \& Kundu, S. (2002). Explaining the growth of E-Commerce corporations (ECCs): An extension and application of the eclectic paradigm. Journal of International Business Studies, 33(4), 679-697.

Steinberg, P. J., Procher, V. D., \& Urbig, D. (2017). Too much or too little of R\&D offshoring: The impact of captive offshoring and contract offshoring on innovation performance. Research Policy, 46(10), 1810-1823.

Stringfellow, A., Teagarden, M. B., \& Nie, W. (2008). Invisible costs in offshoring services work. Journal of Operations Management, 26(2), 164-179.

Stroe, S., Parida, V., \& Wincent, J. (2018). Effectuation or causation: An fsQCA analysis of entrepreneurial passion, risk perception, and self-efficacy. Journal of Business Research, 89(C), 265-272.

Teng, J. T. C., Myun Joong, C., \& Grover, V. (1995). Decisions to outsource information systems functions: Testing a strategy, theoretic discrepancy model. Decision Sciences, 26(1), 75-103.

Thakur-Wernz, P., \& Bruyaka, O. (2017). Co-evolutionary perspective on sourcing portfolios: Examining sourcing choices for clinical trials of bio-pharmaceutical firms. Management International Review, 57(6), 909-946.

Thakur-Wernz, P., Bruyaka, O., \& Contractor, F. (2020). Antecedents and relative performance of sourcing choices for new product development projects. Technovation. https://doi.org/10.1016/j.techn ovation.2019.102097

Van De Ven, A. H., \& Drazin, R. (1985). The concept of fit in contingency theory. Research In Organizational Behavior, 7, 333-365.

Verbeke, A., Ciravegna, L., Lopez, L. E., \& Kundu, S. K. (2019). Five configurations of opportunism in international market entry. Journal of Management Studies, 56(7), 1287-1313.

Williamson, O. E. (1991). Comparative economic organization: The analysis of discrete structural alternatives. Administrative Science Quarterly, 36(2), 269-296.

Williamson, O. E. (2008). Outsourcing: Transaction cost economics and supply chain management. Journal of Supply Chain Management: A Global Review of Purchasing and Supply, 44(2), 5-16.

Witt, M. A., \& Jackson, G. (2016). Varieties of capitalism and institutional comparative advantage: A test and reinterpretation. Journal of International Business Studies, 47(7), 778-806.

Zaheer, A., \& Hernandez, E. (2011). The geographic scope of the MNC and its alliance portfolio: Resolving the paradox of distance. Global Strategy Journal, 1(1-2), 109-126.

Publisher's Note Springer Nature remains neutral with regard to jurisdictional claims in published maps and institutional affiliations. 